\title{
Çocukluk Çağı Bruselloz Özellikleri ve Hastaneye Yatışta Laboratuvar Belirteçlerinin Tanısal Rolü
}

\section{Features of Childhood Brucellosis and the Diagnostic Role of Laboratory Markers in Hospitalization}

\author{
Ayşe Büyükcam ${ }^{1}$ (D) \\ ${ }^{1}$ Cengiz Gökçek Kadın Doğum ve Çocuk Hastalıkları Hastanesi, Çocuk Enfeksiyon Hastalıkları Bölümü, Gaziantep, Türkiye
}

ORCID ID: A.B. 0000-0002-4015-4210

Attf/Citation: Buyukcam A. Çocukluk çağı bruselloz özellikleri ve hastaneye yatışta laboratuvar belirteçlerinin tanısal rolü. Çocuk Dergisi - Journal of Child 2020;20(3):89-95. https://doi.org/10.26650/jchild.2020.3.819575

öz

Amaç: İnsan brusellozu, birçok hastalı̆̆ı taklit eden sistemik bir hastalıktır ve çocuklarda da teşhis edilmesi çok zor olabilmektedir. Çocukluk çağı brusellozu, ciddi klinik tablolarla karşımıza gelebilir ve komplikasyonlara neden olabilir. Bu çalışmada, çocukluk çă̆ı bruselloz hastalarının özellikleri ile hastaneye yatışta laboratuvar belirteçlerin tanısal rolünün araştırılması amaçlandı.

Gereç ve Yöntemler: Geriye dönük olarak 1 Ocak 2018 ile 31 Aralık 2019 tarihleri arasında bruselloz tanısı alan 0-18 yaş 60 çocuk hasta değerlendirildi. Ayaktan ve hastaneye yatış verilerek izlenen bruselloz hastalarının demografik özellikleri ve klinikleri ile mikrobiyolojik ve diğer laboratuvar bulguları incelendi.

Bulgular: Hastaların yaş ortalaması, $9.3 \pm 4.3$ yıldı ve $\% 41,7$ si kız, $\% 58,3$ 'ü erkek idi. Hastaların \%83,3'ünde eklem tutulumu mevcuttu. Hastaların $\% 33,3$ 'ü yatııılarak izlendi. Kan serum eozinofil sayıları yatan hastalarda

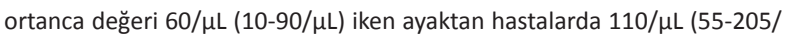
$\mu \mathrm{L})$ değerleri arasında idi $(\mathrm{p}=0,022)$. Kan eozinofil sayısı kesme seviyesi $\leq 90 / \mu \mathrm{L}$ için; (Cl \%95, 54,4-93,9) duyarlılık \%78,95 (Cl \%95, 54,4-93,9) ve özgüllük \%60,00, (Cl \%95,43,3-75,1) olarak bulundu.

Sonuç: Çocukluk çağı brusellozu ülkemiz için önemli bir halk sağlığı sorunu olmaya devam etmektedir. Kan eozinofil düzeyleri, çocukluk çağı brusellozunda hastalık derecesini göstermede ve yatışa karar vermede bir role sahip olabilir ama bu ilişkinin daha iyi anlaşılması, özgüllük ve duyarlılığının değerlendirmesi için daha fazla sayıda hasta ile yeni çalışmalara ihtiyaç vardir.

Anahtar Kelimeler: Bruselloz, çocuk, kan eozinofil sayısı

\section{ABSTRACT}

Objective: Human brucellosis is a systemic disease that mimics many diseases, and its diagnosis is extremely difficult in children. Childhood brucellosis may present with serious clinical pictures and cause complications. This study aimed to investigate the characteristics of childhood brucellosis and the diagnostic role of laboratory markers for hospitalization.

Material and Methods: Sixty children aged between 0 and 18 years who were diagnosed with brucellosis between January 1, 2018 and December 31, 2019 were evaluated retrospectively. The demographic characteristics and clinical, microbiological, and other laboratory findings of brucellosis patients who were followed up as outpatient and inpatient were examined.

Results: The median age of the patients was $9.3 \pm 4.3$ years; $41.7 \%$ were girls and $58.3 \%$ were boys. Joint involvement was $83.3 \%$ of the patients. Total $33.3 \%$ patients were hospitalized. The median value of blood serum eosinophil counts was $60 / \mu \mathrm{L}(10-90 / \mu \mathrm{L})$ in hospitalized patients and $110 /$ $\mu \mathrm{L}(55-205 / \mu \mathrm{L})$ in outpatients $(\mathrm{p}=0.022)$. For blood eosinophil count cutoff level $\leq 90 / \mu \mathrm{L}$ (confidence interval [CI] 95\%, 54.4-93.9), sensitivity was 78.95\% (Cl 95\%, 54.4-93.9) and specificity was 60\%, (Cl 95\%, 43.3-75.1). Conclusion: Childhood brucellosis remains an important public health problem for our country. Blood eosinophil levels may have a role in indicating the degree of disease and deciding hospitalization in childhood brucellosis. New studies with more patients are needed to understand this relationship better and to evaluate its specificity and sensitivity.

Keywords: Brucellosis, child, blood eosinophil count

Sorumlu Yazar/Corresponding Author: Ayşe Büyükcam E-mail: dr.aysebuyukcam@gmail.com

Başvuru/Submitted: 01.11.2020 • Revizyon Talebi/Revision Requested: 20.11.2020 • Son Revizyon/Last Revision Received: 21.11.2020 • Kabul/Accepted: 14.12 .2020 


\section{GíRiş}

Bruselloz, tüm dünyada en sık görülen zoonotik bakteriyel enfeksiyonlardan biridir (1). Bruselloz, enfekte hayvanların (sığır, koyun, keçi, deve, domuz gibi) gıda ürünlerinin (pastörize edilmemiş süt ürünleri gibi) tüketilmesi veya doku/sıvıları ile temas yoluyla veya enfekte aerosol haline gelmiş damlacıkların inhalasyonu ile insanlara bulaşır (2-4). Ayrıca bruselloz, laboratuvardan edinilmiş en sık görülen enfeksiyonlardandır ve bulaşma kolaylığı nedeniyle Amerika Hastalık Kontrol ve Önleme Merkezi tarafindan kategori B biyolojik silah olarak sınıflandırılmıştı (5). İnsanlarda görülen bruselloza, Brucella cinsi organizmalar neden olmaktadır. Dünya çapında önemli bir halk sağlığı sorunu olmaya devam eden bruselloz (4) özellikle birçok gelişmekte olan ülkede sosyoekonomik problemlere de neden olmaktadır (1).

Yetersiz bildirim ve tanı nedeniyle hastalık prevalansına ilişkin net kestirimler olmamasına rağmen, dünya çapında yılda yaklaşık 500.000 yeni vaka görülmektedir. Çocukluk çağı brusellozu vakaların \%10-30'unu oluşturur (4). Bruselloz için endemik bölgeler arasında Türkiye dahil olmak üzere Akdeniz ülkeleri, Orta Doğu, Orta Asya, Çin, Hindistan Yarımadası, Sahra alt Afrika ve Meksika ile Orta ve Güney Amerika'nın bazı kısımları bulunur $(6,7)$. Türkiye'de 2017 yılında morbidite hızı 100.000'de 7,99 olarak bildirilmiştir (8).

Brusella; küçük, zor üreyen, hareketsiz, spor oluşturmayan, gram negatif kokobasillerdir ve doğal plazmidlerden yoksundur. Dış hücre zarı, dominant bir lipopolisakkarit (LPS) bileşenine sahip diğer gram-negatif basillere benzer (9). Daha önce çocuklarda brusellozun nadir veya hafif olduğu düşünülmekle beraber şimdi çocuk yaş grubu dahil tüm yaş gruplarında hastalık yaptı̆ı bilinmektedir. Çocukluk çağı brusellozu daha çok B. melitensis'in enzootik olduğu yerlerde görülür ve ailelerde sıklıkla birden çok vaka ortaya çıkar (9). Bruselloz, çocuklarda teşhis edilmesi çok zor olabilen sistemik bir hastalıktır. Semptomlar, akut veya sinsi olabilir ve genellikle spesifik değildir. En yaygın semptomlar; artralji, kas ağrısı ve sırt ağrısıdır. Ayrıca endemik ülkelerde Brucella spp. küçük çocuklarda önemli bir gizli bakteriyemi nedenidir. Brusellozun ciddi klinik belirtileri arasında endokardit, menenjit, osteomiyelit ve spondilit bulunur. Bruselloza bağlı ciddi sistemik tutulumlarda hastanın intravenöz (IV) tedavi ihtiyacı olması (4) ve yakın takibi nedeni ile hastaneye yatış endikasyonu ortaya çıkmaktadır.

Bu çalışmanın amacı bruselloz tanısı alan, ayaktan ve hastaneye yatş verilerek izlenen çocuk hastalarda demografik, klinik ve laboratuvar özelliklerin değerlendirilmesi ve hastaneye yatışta laboratuvar belirteçlerinin tanısal bir rolünün olup olmadığının araştırılmasıdır.

\section{GEREÇ VE YÖNTEMLER}

Bu çalışmada, 1 Ocak 2018 ile 31 Aralık 2019 tarihleri arasında hastanemize başvuran ve bruselloz tanısı alan $0-18$ yaş 60 çocuk hasta geriye dönük olarak değerlendirildi. Hastanemizde tanı almış veya tanısı doğrulanmış ve takibe alınan henüz tedavi almamış ayaktan veya yatırılan akut bruselloz (< 8 hafta) (10) hastaları dahil edildi.
Bruselloz tanısı; eklem ağrısı, halsizlik, gece terlemesi gibi bruselloz semptomları (10) ile başvuran; pozitif Rose Bengal testi ve Brusella Coombs agglütinasyon testi $\geq 1 / 320(11,12)$ veya Brucella türlerinin kan gibi vücut sıvı örneklerinden izolasyonu ile konuldu. Bruselloz için endokardit, menenjit, osteoartiküler tutulum, nörobruselloz, bakteriyemi, genel durum bozukluğu gibi ciddi enfeksiyon bulguları nedeni IV antibiyotik ihtiyacı olma (4) yatış endikasyonu olarak kabul edildi.

Çalışmaya katılan ayaktan ve yatan hastaların; yaş ve cinsiyet gibi demografik özellikleri, klinik belirti ve bulguları ile mikrobiyolojik sonuçları ve tam kan sayımı, C-reaktif protein (CRP), eritrosit sedimantasyon hızı (ESH), karaciğer enzim seviyeleri (aspartat aminotransferaz [AST], alanin aminotransferaz [ALT], laktat dehidrojenaz [LDH]) dahil laboratuvar bulguları ile Rose Bengal ve Brusella Coombs Agglütinasyon testlerinin sonuçları hastane elektronik kayıtlarından elde edildi ve ayaktan ve yatan bruselloz hastaları karşılaştırıldı. Dış merkezde takipli ve tedavi almakta olan bruselloz hastaları ile bruselloz dışında akut veya sistemik ilaç kullanımı gerektiren kronik hastalığı olan hastalar çalışma dışı bırakıldı. Çalışma süresi boyunca laboratuvarda standart tüp aglütinasyon testi (STA) ve 2-merkaptoetanol aglütinasyon testi rutin olarak yapılamadı. Çalışma, Gaziantep Üniversitesi İlaç Dışı Klinik Araştırmalar Etik Kurulu tarafindan 13/11/2019 tarihinde 2019/442 numaralı kararla onaylandı.

İstatistik Analiz: Sürekli değişkenlerin dağılımının normalliği Shaphiro Wilk testi ile test edildi. Normal dağılmayan veriler için 2 bağımsız grubu karşılaştırmak için Mann Whitney $U$ testi, normal olmayan verileri üç grupta karşılaştırmak için Kruskal Wallis ve Dunn çoklu karşılaştırma testleri kullanıldı. İi kategorik değişken arasındaki ilişkiyi araştırmak için ki-kare testi uygulandı ve sayısal değişkenler arasındaki korelasyonları değerlendirmek için Spearman sıra korelasyon katsayısı hesaplanmıştır. Bazı sayısal ölçümlerin tanısal değerlerini belirlemek için ROC eğri analizi yapıldı. İstatistiksel analiz Statistical Packages for the Social Sciences (SPSS) for Windows 24.0 sürümü ile yapıldı ve $p$ $<0,05$ değeri istatistiksel olarak anlamlı kabul edildi.

\section{BULGULAR}

Çalışmaya hastanemizde bruselloz tanısı alan 60 çocuk hasta katılmıştır. Bunların \%41,7'si ( $n=25)$ kız, \%58,3'ü ( $n=35)$ erkek idi. Hastaların yaş ortalaması 9,3 $\pm 4,3$ yıl ve yaş ortancası 9,7 (minimum-maksimum: 1-17,9 yıl) yıldı. Hastaların \%83,3'ünde $(n=50)$ eklem tutulumu ve \%11,7 ( $n=7)^{\prime}$ 'sinde ateş yakınması vardı. İki hastanın bruselloz tanısı ile birlikte nörolojik bulguları (dengesiz yürüme, çift görme, baş ağrısı ve yavaş konuşma) mevcuttu. Hastaların \%33,3'ü $(n=20)$ yatırıldı. Yatrılan hastalara; eklem tutulumuna bağlı yürüyememe $(n=16)$, nörolojik bulguların olması ( $n=1)$, yüksek ateş ve genel durum bozukluğu $(n=2)$ olması ve ateş, nörolojik bulgular ve yürürken zorlanma $(n=1)$ nedeni ile yatış verildi. Ayaktan ve yatan hastaların ayrınthlı demografik ve klinik özellikleri Tablo 1'de verilmiştir. Yatan ve ayaktan takip edilen hastaların cinsiyet, yaş ve Brusella Coombs Aglütinasyon test dağılımları benzerdi. Yatan üç hastanın kan kültüründe Brucella melitensis üremesi oldu. 
Tablo 1: Ayaktan izlenen ve yatan çocuk bruselloz hastalarının demografik ve klinik özellikleri.

\begin{tabular}{|c|c|c|c|c|c|c|}
\hline & & \multicolumn{4}{|c|}{ YATIŞ } & \multirow[b]{3}{*}{$p$} \\
\hline & & \multicolumn{2}{|c|}{ Evet $(n=20)$} & \multicolumn{2}{|c|}{ Hayır $(n=40)$} & \\
\hline & & $\mathbf{n}$ & $\%$ & $\mathrm{n}$ & $\%$ & \\
\hline \multirow[t]{2}{*}{ Cinsiyet } & Kız & 9 & 45 & 16 & 40 & 0,711 \\
\hline & Erkek & 11 & 55 & 24 & 60 & \\
\hline \multirow[t]{3}{*}{ Yaş Grupları } & 5 yaş ve altı & 6 & 30 & 9 & 22 & 0,817 \\
\hline & 6-9 yaş & 6 & 30 & 13 & 32,5 & \\
\hline & 10 yaş ve üstü & 8 & 40 & 18 & 45 & \\
\hline \multirow[t]{3}{*}{ Brusella Coombs Aglütinasyon Testi } & $1 / 1280$ & 15 & 78,9 & 22 & 55 & 0,156 \\
\hline & $1 / 640$ & 3 & 15,8 & 9 & 22,5 & \\
\hline & $1 / 320$ & 1 & 5,3 & 9 & 22,5 & \\
\hline \multirow[t]{3}{*}{ Eklem Tutulumu } & Evet & 17 & 85 & 33 & 82,5 & 0,252 \\
\hline & Hayır & 3 & 15 & 3 & 7,5 & \\
\hline & Bilinmiyor & 0 & 0 & 4 & 10 & \\
\hline \multirow[t]{3}{*}{ Ateş } & Evet & 3 & 15 & 4 & 10 & 0,526 \\
\hline & Hayır & 17 & 85 & 34 & 85 & \\
\hline & Bilinmiyor & 0 & 0 & 2 & 5 & \\
\hline \multirow[t]{3}{*}{ Brusella pozitifliği ve nörolojik bulgular } & Evet & 2 & 10 & 0 & 0 & 0,081 \\
\hline & Hayır & 18 & 90 & 38 & 95 & \\
\hline & Bilinmiyor & 0 & 0 & 2 & 5 & \\
\hline
\end{tabular}

Yatış verilen hastalar ile ayaktan tedavi verilen hastaların tanı anındaki tam kan sayımında; beyaz küre, nötrofil, lenfosit, monosit, eozinofil, trombosit sayıları ve ortalama trombosit hacmi (MPV) değerleri ile kan serum biyokimya değerlerinde
LDH, ALT, AST, CRP ve ayrıca ESH değerleri karşılaştırıldı (Tablo 2). Tüm hastalarda Brucella dışında başka bir mikrobiyolojik etken gösterilmedi ve paraziter hastalık açısından bilinen bir yakınmaları yoktu. Hastaların sürekli ağızdan ilaç kullanımını

Tablo 2: Ayaktan izlenen ve yatan çocuk bruselloz hastalarının laboratuvar değerleri.

\begin{tabular}{|c|c|c|c|c|c|}
\hline & \multicolumn{4}{|c|}{ YATIŞ } & \multirow[b]{3}{*}{$p$} \\
\hline & \multicolumn{2}{|r|}{ Evet $(n=20)$} & \multicolumn{2}{|r|}{ Hayır $(n=40)$} & \\
\hline & $\mathbf{n}$ & $\begin{array}{c}\text { Ortanca Değer } \\
\text { (minimum-maksimum) }\end{array}$ & $\mathrm{n}$ & $\begin{array}{c}\text { Ortanca Değer } \\
\text { (minimum-maksimum) }\end{array}$ & \\
\hline CRP* $(0,01-6 \mathrm{mg} / \mathrm{L})$ & (20) & $2,96[1,05-9,56]$ & (36) & $1,89[0,5-8,5]$ & 0,278 \\
\hline LDH (U/L) & (16) & $285,5[262-412]$ & (32) & $271,5[215-322,5]$ & 0,099 \\
\hline ALT (U/L) & (18) & $30[20-50]$ & (38) & $27[16-36]$ & 0,229 \\
\hline AST (U/L) & (18) & $38[28-56]$ & (38) & $34[23-46]$ & 0,079 \\
\hline Beyaz küre $(/ \mu \mathrm{L})$ & (19) & 8670 [6680 -9590] & (40) & 8345 [7425 -9640] & 0,554 \\
\hline Nötrofil $(/ \mu \mathrm{L})$ & (19) & 3760 [2600 -4990] & (40) & 3145 [2595 -4455] & 0,808 \\
\hline Lenfosit $(/ \mu \mathrm{L})$ & (19) & 3060 [2560 -4720] & (40) & 4050 [2970 -4910] & 0,168 \\
\hline Monosit $(/ \mu \mathrm{L})$ & (19) & $680[510-860]$ & (40) & $665[550-745]$ & 0,955 \\
\hline Eozinofil $(/ \mu \mathrm{L})$ & (19) & $60[10-90]$ & (40) & 110 [55 -205] & $0,022 *$ \\
\hline Trombosit $(/ \mu \mathrm{L})$ & (19) & 319000 [230000 -394000] & (40) & 300500 [259000 -362500] & 0,752 \\
\hline MPV (fL) & (18) & $9,35[8,7-9,9]$ & (40) & $9,2[8,75-9,6]$ & 0,495 \\
\hline $\mathrm{ESH}^{* *}(2-20 \mathrm{~mm} / \mathrm{saat})$ & (15) & $30[18-36]$ & (40) & $26,5[17-36]$ & 0,495 \\
\hline
\end{tabular}

*CRP: C-reaktif protein

**ESH: Eritrosit sedimentasyon hızı 
gerektiren bir kronik hastalığı yoktu. Bir hastanın hafif şiddette astımı, bir hastanın skolyozu, bir hastanın kasıkta inguinal hernisi ve bir hastanın sedef hastalığı vardı ve hiçbiri ağızdan ilaç kullanmıyordu. Ayaktan ve yatan bruselloz tanısı almış çocuk hastaların beyaz küre $(p=0,554)$, nötrofil $(p=0,808)$, lenfosit $(p=0,168)$, monosit $(p=0,955)$, trombosit $(p=0,752)$ sayıları ve MPV $(p=0,495)$ değerleri benzerdi. Ayrıca LDH $(p=0,099)$, ALT $(p=0,229)$, AST $(p=0,079), \operatorname{CRP}(p=0,278)$ ve ESH $(p=0,495)$ değerleri arasında istatistiki açıdan anlamlı bir fark yoktu (Tablo 2 ).

Kan serum eozinofil sayıları yatan hastalarda ortanca değeri $60 / \mu \mathrm{L}(10-90 / \mu \mathrm{L})$ iken ayaktan hastalarda $110 / \mu \mathrm{L}(55-205 / \mu \mathrm{L})$ değerleri arasında ve daha yüksekti. İstatistiksel olarak anlamlı fark mevcuttu $(p=0,022)$. ROC analizi ile parametrelerin analizine dayalı olarak kan eozinofil sayısının, bruselloz için yatan hastalarda istatiksel olarak farklı olduğu gösterilmiştir.

Ayaktan ve yatan hastaların eozinofil sayıları için ROC analizinde ROC eğrisi altındaki alan $0,686 \pm 0,07$ ve $p=0,0171$ saptandı. Kesme seviyesi 90/ $\mu \mathrm{L}$ ve alt için (Cl \%95, 54,4-93,9) duyarlılık (sensivite) \%78,95 (Cl \%95, 54,4-93,9) ve özgüllük (spesifite) \%60.00, (Cl \%95, 43,3-75,1) olarak bulundu (Şekil 1).

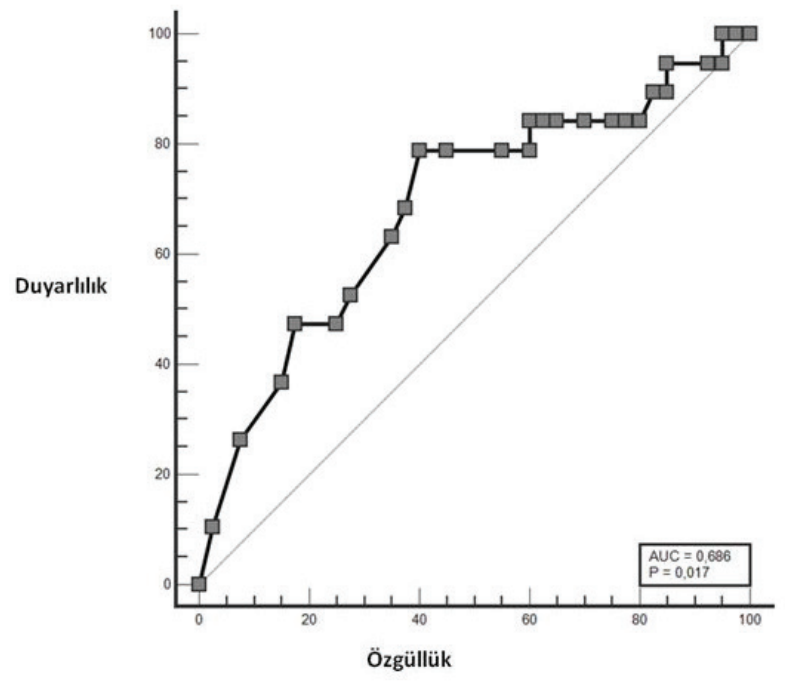

Şekil 1: Kan eozinofil değeri ROC analiz eğrisi.

\section{TARTIŞMA}

İnsan brusellozu, diğer birçok hastalığı taklit eden sistemik bir hastalıktır. Yanlış tanı nedeniyle artan morbiditeye yol açabilir (13). Hastalar genellikle geniş bir semptom yelpazesine sahiptir (1). Brusellozun, çocuklarda teşhis edilmesi de çok zor olabilmektedir. En yaygın fiziksel yakınmalar; artralji, kas ağrısı ve sırt ağrısıdır. Yetişkin vakaların çoğunda yorgunluk, terleme, titreme, iştahsızlık, baş ağrısı, kilo kaybı ve halsizlik gibi sistemik semptomlar bildirilir, ancak çocuklarda bu semptomlar daha az görülür. Brusellozun ciddi tabloları arasında endokardit, menenjit, osteomiyelit ve spondilit bulunur (4).

Klinik örneklerden Brucella spp. kültür ve etkenin tanımlanması tanıda altın standart yöntemdir ama her zaman mümkün olmamaktadır ve vakaların çok az bir kısmında üreme olmaktadır. Akut ve konvalesan faz serum numunelerinden $\geq 2$ hafta aralarla elde edilen Brucella antikor titrelerinde dört kat veya daha fazla artış olduğunun gösterilmesi tanı için kullanılan diğer bir yöntemdir. Bununla birlikte tüm serolojik sonuçların hastanın öyküsü ve fizik muayenesi ışı̆̆ında yorumlanması gerektiğini unutmamak önemlidir $(3,4)$. Ayrıca biyokimyasal testlerde CRP, ESH gibi inflamatuvar belirteçlerin ve AST, ALT ve GTT gibi karaciğer enzimlerinin artmış seviyelerinin tanıyı destekleyebileceği bildirilmiştir. Bununla ilgili çeşitli çalışmalar yapılmıştır (14). Arapović ve ark., sistemik tutulumu olmayan bruselloz hastalarında CRP veya ESH $(p<0,001)$ anlamlı derecede daha yüksek değerlerini tespit etmişlerdir (15). Olt ve ark. ise bruselloz tanısı alan erişkin hastalarda yaptıkları bir çalışmada kan nötrofil/lenfosit oranının bruselloz ile ilişkili olduğunu göstermişlerdir (16). Çocukluk çağı brusellozunda ise Bozdemir ve ark., artmış nötrofil/lenfosit oranının inflamasyonun bir göstergesi olarak kullanılabileceğini bildirmişlerdir (17). Kazanasmaz ve ark.'nın 332 çocuk bruselloz hastasında yaptı̆ı çalışmalarında ise bruselloz tanısı ile kontrol grupları arasında medyan kan beyaz küre, nötrofil, lenfosit, nötrofil/lenfosit oranı ve trombosit değerleri açısından anlamlı fark bulunmazken, medyan AST, ALT, GGT, CRP ve ESH değerleri bruselloz tanısı alan grupta anlamlı olarak daha yüksek bulunmuştur. Bununla birlikte, bu belirteçlerin ayırıcı tanıdaki rolü, düşük özgüllükleri ve duyarlılıkları nedeniyle sınırlı olduğu belirtilmiştir (14).

Brucella spp. retiküloendotelyal sistemin santral (kemik iliği) ve periferik (dalak) organlarına özel tropizme sahiptir (18). Hematolojik anormallikler brusellozda yaygındır; trombositopeni, lökopeni, anemi veya pansitopeni meydana gelebilir (4). Çocukluk çağı brusellozunda hematolojik anormalliklerin sıklığı ve çeşitliliği hakkında nispeten az veri bildirilmiştir (18). Hipersplenizm, hemofagositoz ve kemik iliğinin granülomatöz lezyonları, periferik kandaki bu anormalliklerin meydana gelmesinde rol oynayan faktörler arasındadır (19). Bununla birlikte birden fazla mekanizmanın sorumlu olması daha olası görülmektedir (20). Ancak hematolojik parametrelerdeki değişikliklerin tanısal değeri yoktur ve bruselloz tedavisi ile hızla normal değerlere dönmektedirler (17).

MPV, trombosit aktivasyonu ve üretiminin bir göstergesidir. Daha önce yapılan çalışmalar, MPV ile inflamatuvar hastalık arasında bir korelasyon olduğunu bildirmiştir. MPV değerinin bruselloz hastalarında trombosit fonksiyonunun değerlendirilmesinde kullanılabileceği düşünülmüştür (21). Brusellozda interferon- $\gamma$, tümör nekroz faktörü $\alpha$, interlökin 1 (IL-1) ve IL12 'nin gibi proinflamatuvar sitokinlerin aşırı salınımı trombositlerin olgunlaşmasını etkileyebilir ve bruselloz enfeksiyonu sırasında trombosit boyutunda bir azalmaya neden olabilir. Bununla birlikte MPV ve bruselloz ilişkisi ile ilgili literatürdeki yayınlarda farklı sonuçlar bulunmuştur (21). Bozdemir ve ark.'nın yaptığı çalışmada, 60 brusellozlu çocukta MPV'yi 55 sağlıklı kontrol çocukla karşılaştırdıklarında anlamlı ve daha düşük bulunmuştur $(p=0,049)(17)$. MPV değeri bruselloz vakalarında tedavi sonrası diğer hematolojik parametreler gibi düzeldiği gösterilmiştir $(22,23)$.

Brusella enfeksiyonu vücuttaki herhangi bir organı veya dokuyu tutabilir. Etkilenen en yaygın sistemler lokomotor, 
gastrointestinal, genitoüriner, hematolojik, kardiyovasküler, solunum ve merkezi sinir sistemleridir (24). Brucella spp., fakültatif hücre içi patojenler olduğu için hücre içi öldürmeyi sağlayan ajanlar, Brusella enfeksiyonlarının ortadan kaldırılması için gereklidir. Monoterapi ile relaps riski nedeniyle, genellikle kombinasyon tedavisi önerilir. Çocuklarda, rifampisin ile kombinasyon halinde doksisiklin veya trimetoprim-sülfametoksazol (TMP-SMX) sıklıkla komplike olmayan enfeksiyonlar için kullanılır. Çocuk hastalarda, ciddi enfeksiyonlarda (örn., endokardit, menenjit, osteoartiküler) üçlü ilaç tedavisi önerilir. Doksisiklin veya TMP-SMX ve rifampisin ile birlikte ilk 7-14 gün bir aminoglikozid (streptomisin, gentamisin) uygulanması önerilir (4) ve çoğunlukla IV tedavi alacak hastalara yatış verilir. Çalışmamızda bruselloz için endokardit, menenjit, osteoartiküler tutulum, nörobruselloz, bakteriyemi, genel durum bozukluğu gibi ciddi enfeksiyon bulguları ile birlikte IV antibiyotik ihtiyacı olma yatış endikasyonu olarak kabul edildi. Ayaktan oral bruselloz tedavisi ile izlenen hastalar ile ciddi enfeksiyon bulguları nedeni ile yatış ihtiyacı olan çocuk hastaların beyaz küre, nötrofil, lenfosit, monosit, trombosit sayıları ve MPV değerleri ile LDH, ALT, AST, CRP ve ESH değerleri karşılaştırıldığında bir fark olmadığı görüldü. Bununla birlikte eozinofil sayıları yatan hastalara göre ayaktan hastalarda daha yüksekti.

Eozinofiller, morfolojileri, ürünleri ve spesifik hastalıklarla ilişkileri açısından diğer lökositlerden ayrılır. Eozinofiller, yaklaşık $8 \mu \mathrm{m}$ çapında ve çift loblu bir çekirdeğe sahip bölünmeyen, tamamen farklılaşmış hücrelerdir. T hücre türevi interlökin-3 (IL-3), granülosit makrofaj koloni uyarıcı faktör (GM-CSF) ve özellikle IL-5'in kontrolü altında kemik iliğindeki kök hücre öncülerinden farklılaşırlar (25). Periferik kan eozinofil yüksekliğine ( $\geq 500$ eozinofil/mikroL) alerjik, enfeksiyöz, inflamatuvar ve neoplastik bozukluklar dahil olmak üzere çok sayıda durum neden olabilir $(26,27)$.

Hastaların tanı, prognozu veya izlenmesi için eozinofil sayısını değerlendiren çok sayıda yayın vardır (28). 1893'ten beri eozinopeni, bakteriyel enfeksiyon teşhisine yardımcı olan biyolojik bir testtir. Literatürde çeşitli yayınlar bu hipotezi özellikle yoğun bakım, pediatri birimlerinde yapılan çalışmalar ile doğrulamıştır. Ayrıca bu belirtecin değeri vasküler serebral hastalıklarda ve koroner bypassta da tespit edilmiştir (29). Enfeksiyonu olan hastalarda; eozinopeni, nötrofili ve lenfopeni yaygın olarak görülmektedir. Akut enfeksiyon eozinopenisinin; enfeksiyon bölgesinde eozinofillerin sekestrasyonunun bir sonucu olduğu düşünülse de, adrenal kortikosteroidler ve epinefrinin aracılık ettiği diğer stres tepkileri de eozinopeni ile sonuçlanabilir (28). Gil ve ark. yaptıkları çalışmada, $40 / \mu l$ 'den daha düşük bir eozinofil sayısının, yüksek CRP değerine neden olan enfeksiyöz olmayan nedenlerin enfeksiyon kaynaklı nedenlerden ayırt etmesinde çok spesifik bir belirteç olduğunu bulmuşlardır (<40) $\mu l^{\prime}$ lik bir kesim eozinopeni değeri için, duyarlılık \%56, özgüllük \%92) (30). Efstathiou ve ark., eozinofil sayısının <40/ $\mu l^{\prime}$ lik değeri için (CRP $>6 \mathrm{mg} / \mathrm{dl}$ ve ferritin $<500 \mu \mathrm{g} / \mathrm{l}$ ile kombinasyonu ile birlikte) kaynağı bilinmeyen ateşi olan hastalarda iyi bir bağımsız enfeksiyon belirteci olduğunu bulmuşlardır (\%91,4 duyarlılık, \%92,3 özgüllük) (31). Debray ve ark.'nın bakteriyel ve viral menenjitli çocuk hastalarda yaptıkları çalışmalarında, ortalama eozinofil sayısı belgelenmiş bakteriyel menenjit grubunda $15 \pm 34$ / $\mathrm{mm}^{3}$ iken aseptik menenjit grubunda $132 \pm 167 / \mathrm{mm}^{3}(\mathrm{p}<0,0001)$ bulunmuştur. Bakteriyel menenjit tanısı için en iyi eşik değer; $\% 80$ duyarlılık ve $\% 73$ özgüllük ve 2,9 olasılık oranı ile eozinofil sayısı $<5 / \mathrm{mm}^{3}$ olarak bulunmuştur (32). Lavoignet ve ark., acil serviste beyaz küre sayımı içinde eozinopeninin, idrar ve safra yolu enfeksiyonu tanısı için en etkili parametre olduğunu belirtmişlerdir (33).

Akut enfeksiyonda, eozinopeninin altta yatan mekanizma(ları) tam olarak anlaşılmamıştır. Kemik iliğinde eozinofillerin mobilizasyonunun/üretiminin azalması ve/veya dokulara artan yönlendirmenin bir rol oynayıp oynamadığı açık değildir. Hassani ve ark., doğal bağışıklıklıkta meydana gelen dolaşımdaki eozinopeninin nedeninin eozinofillerin dokulara CD49d aracılı dönüşünün aracılık etmesi ile ilgili olabileceğini belirtmektedirler (34).

Literatürde bruselloz ve eozinofil ilişkisi ile ilgili çalışmalar kısıtlıdır. Galanakis ve ark. yaptığı çalışmada 52 brusellozlu çocuğun \%19'unda eozinofili tespit edilmiştir (35). Parlak ve ark.'nın yaptığı 426 bruselloz tanılı çocuk hastada yaptığı çalışmada ise hastaların \%5'inde eozinofili tespit edilmiştir (36). Bruselloz, proliferasyon yapan kemik iliği hücreleri üzerinde doğrudan bir inhibitör etki gösterirler, parazitleşmiş makrofajları indükleyebilir ve pansitopeninin bir nedeni olarak hematopoezi inhibe eden mediyatörleri serbest bırakmak için lenfositleri aktive edebilirler (20). Bununla birlikte sistem tutulumu olan, daha ağır bir klinik tablosu olan, yatş gereksinimi olan bruselloz tanısı alan hastalarımızda neden kan eozinofil değerinin anlamlı olarak daha düşük olduğu konusunda literatürde ışık tutacak bir çalışma yoktur. Akut enfeksiyonda eozinopeni görülebilmesi yukarda belirtildiği gibi bilinen bir bulgu olmakla birlikte çocukluk çağı brusellozunda hastalığın şiddeti ile olası ilişkisi çalışmamızda ilk kez gösterilmiştir. Bununla birlikte çalışmamızda vaka sayısı kısıtlıdır ve eozinofil ile bruselloz ilişkisinin anlaşılabilmesi için daha fazla hasta ile yapılan çalışmalara ihtiyaç vardır.

Sonuç olarak çalışmamız; bulguları ağır seyreden, IV tedavi ihtiyacı olan, yatış gerektiren çocuk bruselloz hastaları ile kan eozinofil düzeyi arasında bir korelasyon olduğunu desteklemektedir ve çocukluk çağı brusellozu hastalarında hastalık derecesini göstermede ve yatş̧a karar vermede bir role sahip olabileceğini gösteren ilk çalışmadır.

Etik Komite Onayı: Bu çalışma için etik komite onayı Gaziantep Üniversitesi illaç Dışı Klinik Araştırmalar Etik Kurulu'ndan alınmıştır. (tarih: 13.11.2019 no: 2019/442)

Bilgilendirilmiş Onam: Katılımcılardan bilgilendirilmiş onam alınmıştır.

Hakem Değerlendirmesi: Dış bağımsız.

Yazar Katkıları: Çalışma Konsepti/Tasarım-A.B.; Veri Toplama- A.B.; Veri Analizi/Yorumlama- A.B.; Yazı Taslağı- A.B.; İçeriğin Eleştirel İncelemesiA.B.; Son Onay ve Sorumluluk- A.B.; Malzeme ve Teknik Destek- A.B.; Süpervizyon- A.B.

Çıkar Çatışması: Yazarlar çıkar çatışması beyan etmemişlerdir.

Finansal Destek: Yazarlar finansal destek beyan etmemişlerdir. 
Ethics Committee Approval: Ethics committee approval for this study was obtained from the Ethics Committee of Gaziantep University Medical Clinic. (date: 13.11.2019 no: 2019/442)

Informed Consent: Written consent was obtained from the participants.

Peer Review: Externally peer-reviewed.

Author Contributions: Conception/Design of Study- A.B.; Data Acquisition- A.B.; Data Analysis/Interpretation- A.B.; Drafting Manuscript- A.B.; Critical Revision of Manuscript- A.B.; Final Approval and Accountability- A.B.; Technical or Material Support- A.B.; Supervision- A.B.

Conflict of Interest: Authors declared no conflict of interest.

Financial Disclosure: Authors declared no financial support.

\section{KAYNAKLAR/REFERENCES}

1. Bukhari EE. Pediatric brucellosis. An update review for the new millennium. Saudi Med J 2018 Apr;39(4):336-41.

2. Pappas G, Akritidis N, Bosilkovski M, Tsianos E. Brucellosis. N Engl J Med 2005 Jun 2;352(22):2325-36.

3. CDC. Brucellosis reference guide: Exposures, testing, and prevention. 2017 [cited 2020]; Available from: https://www.cdc. gov/brucellosis/pdf/brucellosi-reference-guide.pdf.

4. Downes KJ. Brucella. In: Robert M. Klıegman M, Joseph W. St Geme III M, Nathan J. Blum M, Samır S. Shah M, MSCE, Robert C. Tasker M, MD, Karen M. Wilson M, MPH, et al., editors. Nelson Texbook of Pediatrics. 21 ed. p. 6199-206.

5. Hanefi C. Gul, Erdem H. Brucellosis (Brucella Species). In: John E. Bennett MD, Raphael Dolin MD, MD MJB, editors. Mandell, Douglas, and Bennett's Principles and Practice of Infectious Diseases, . 9 ed2020. p. 2753-8.e2.

6. Seleem MN, Boyle SM, Sriranganathan N. Brucellosis: a reemerging zoonosis. Vet Microbiol 2010 Jan 27;140(3-4):392-8.

7. Pappas G, Papadimitriou P, Akritidis N, Christou L, Tsianos EV. The new global map of human brucellosis. Lancet Infect Dis 2006 Feb;6(2):91-9.

8. T.C. Sağlık Bakanlığı, Halk Sağlığı Genel Müdürlüğü, Türkiye Bruselloz istatistik Verileri. 2017 [cited 2020]; Available from: hsgm.saglik.gov.tr/tr/zoonotikvektorel-bruselloz/istatistik.

9. Young EJ. Brucellosis. In: James D. Cherry MD M, Gail J. Harrison MD, Sheldon L. Kaplan MD, William J. Steinbach MD, Peter J. Hotez MD P, editors. Feigin and Cherry's Textbook of Pediatric Infectious Diseases. 8 ed2019. p. 1156-9.e3.

10. Erdem H, Elaldi N, Ak O, Gulsun S, Tekin R, Ulug M, et al. Genitourinary brucellosis: results of a multicentric study. Clinical microbiology and infection: The official publication of the European Society of Clinical Microbiology and Infectious Diseases. 2014 Nov;20(11):0847-53.

11. Klinik, Bakteriyoloji, Tanı, Standartları, Çalışma, Grubu. Brusellozun Mikrobiolojik tanısı. 2015 [cited 2020]; Available from: https:// hsgm.saglik.gov.tr/depo/birimler/Mikrobiyoloji_Referans_ Laboratuvarlari_ve_Biyolojik_Urunler_DB/rehberler/UMS_ LabTaniRehberi_Cilt_1.pdf.
12. CDC. Brucellosis-Serology. 2012 [cited 2020]; Available from: https://www.cdc.gov/brucellosis/clinicians/serology.html.

13. al-Eissa $\mathrm{Y}$, al-Zamil F, al-Mugeiren $\mathrm{M}$, al-Rasheed $\mathrm{S}$, al-Sanie $\mathrm{A}$, alMazyad A. Childhood brucellosis: a deceptive infectious disease. Scand J Infect Dis 1991;23(2):129-33.

14. Kazanasmaz H, Geter S. Investigation of the sensitivity and specificity of laboratory tests used in differential diagnosis of childhood brucellosis. Cureus. 2020 Jan 23;12(1):e6756.

15. Arapovic J, Spicic S, Ostojic M, Duvnjak S, Arapovic M, Nikolic J, et al. Epidemiological, clinical and molecular characterization of human brucellosis in Bosnia and Herzegovina - An ongoing brucellosis outbreak. Acta Med Acad 2018 May;47(1):50-60.

16. Olt $\mathrm{S}$, Ergenc $\mathrm{H}$, Acikgoz SB. Predictive contribution of neutrophil/ lymphocyte ratio in diagnosis of brucellosis. Biomed Res Int 2015;2015:210502.

17. Bozdemir ŞE, Altıntop YA, Uytun S, Aslaner H, Torun YA. Diagnostic role of mean platelet volume and neutrophil to lymphocyte ratio in childhood brucellosis. Korean J Intern Med 2017 Nov;32(6):1075-81.

18. Aypak A, Aypak C, Bayram Y. Hematological findings in children with brucellosis. Pediatr Int 2015 Dec;57(6):1108-11.

19. Tanir G, Tufekci SB, Tuygun N. Presentation, complications, and treatment outcome of brucellosis in Turkish children. Pediatr Int 2009 Feb;51(1):114-9.

20. Citak EC, Citak FE, Tanyeri B, Arman D. Hematologic manifestations of brucellosis in children: 5 years experience of an anatolian center. J Pediatr Hematol Oncol 2010 Mar;32(2):137-40.

21. Okan DH, Gökmen Z, Seyit B, Yuksel K, Cevdet Z, Deniz A. Mean platelet volume in brucellosis: correlation between brucella standard serum agglutination test results, platelet count, and C-reactive protein. Afr Health Sci 2014 Dec;14(4):797-801.

22. Küçükbayrak A, Taş T, Tosun M, Aktaş G, Alçelik A, Necati Hakyemez I, et al. Could thrombocyte parameters be an inflammatory marker in the brucellosis? Med Glas (Zenica) 2013 Feb;10(1):35-9.

23. Aktar F, Tekin R, Bektas MS, Güneş $A$, Köşker M, Ertuğrul S, et al. Diagnostic role of inflammatory markers in pediatric Brucella arthritis. Ital J Pediatr 2016 Jan 11;42:3.

24. Okur M, Erbey F, Bektaş MS, Kaya A, Doğan M, Acar MN, et al. Retrospective clinical and laboratory evaluation of children with brucellosis. Pediatr Int 2012 Apr;54(2):215-8.

25. Downes KJ. Brucella. In: Robert M. Klıegman M, Joseph W. St Geme III M, Nathan J. Blum M, Samır S. Shah M, MSCE, Robert C. Tasker M, MD, Karen M. Wilson M, MPH, et al., editors. Nelson Texbook of Pediatrics. 21 ed2020. p. 6199-206.

26. Benjamin L. Wright, Vickery BP. Eosinophils. In: Robert M. Klıegman M, Joseph W. St Geme III M, Nathan J. Blum M, Samır S. Shah M, MSCE, Robert C. Tasker M, MD, Karen M. Wilson M, MPH, et al., editors. Nelson Text Book. 21 ed2020. p. 4739-48.

27. O'Connell EM, Nutman TB. Eosinophilia in infectious diseases. Immunol Allergy Clin North Am 2015 Aug;35(3):493-522.

28. Butt NM, Lambert J, Ali S, Beer PA, Cross NC, Duncombe A, et al. Guideline for the investigation and management of eosinophilia. Br J Haematol 2017 Feb;176(4):553-72.

29. Karakonstantis S, Kalemaki D, Tzagkarakis E, Lydakis C. Pitfalls in studies of eosinopenia and neutrophil-to-lymphocyte count ratio. Infect Dis (Lond) 2018 Mar;50(3):163-74.

30. Gil H, Bouldoires B, Bailly B, Meaux Ruault N, Humbert S, MagyBertrand N. L'éosinopénie en 2018 [Eosinopenia in 2018]. Rev Med Interne 2019 Mar;40(3):173-7. 
31. Gil H, Magy N, Mauny F, Dupond JL. Valeur de l'eosinopenie dans le diagnostic des syndromes inflammatoires: un "vieux" marqueur revisite [Value of eosinopenia in inflammatory disorders: an "old" marker revisited]. Rev Med Interne. 2003 Jul;24(7):431-5.

32. Efstathiou SP, Pefanis AV, Tsiakou AG, Skeva, II, Tsioulos DI, Achimastos $A D$, et al. Fever of unknown origin: discrimination between infectious and non-infectious causes. Eur J Intern Med 2010 Apr;21(2):137-43.

33. Debray A, Nathanson S, Moulin F, Salomon J, Davido B. Eosinopenia as a marker of diagnosis and prognostic to distinguish bacterial from aseptic meningitis in pediatrics. Eur J Clin Microbiol Infect Dis 2019 Oct;38(10):1821-7.

34. Lavoignet $C E$, Le Borgne $P$, Chabrier S, Bidoire J, Slimani $H$, Chevrolet-Lavoignet J, et al. White blood cell count and eosinopenia as valuable tools for the diagnosis of bacterial infections in the ED. Eur J Clin Microbiol Infect Dis. 2019 Aug;38(8):1523-32.
35. Hassani M, Leijte G, Bruse N, Kox M, Pickkers P, Vrisekoop N, et al. Differentiation and activation of eosinophils in the human bone marrow during experimental human endotoxemia. J Leukoc Biol 2020 Nov;108(5):1665-71.

36. Galanakis E, Bourantas KL, Leveidiotou S, Lapatsanis PD. Childhood brucellosis in north-western Greece: a retrospective analysis. Eur J Pediatr 1996 Jan;155(1):1-6.

37. Parlak M, Akbayram S, Dogan M, Tuncer O, Bayram Y, Ceylan N, et al. Clinical manifestations and laboratory findings of 496 children with brucellosis in Van, Turkey. Pediatr Int 2015 Aug;57(4):586-9. 